\title{
Insulin-Like Growth Factor I Promotes Maturation and Inhibits Apoptosis of Immature Cord Blood Monocyte-Derived Dendritic Cells through MEK and PI 3-Kinase Pathways
}

\author{
ENMEI LIU, HELEN K.W. LAW, AND YU-LUNG LAU \\ Department of Paediatrics and Adolescent Medicine, Faculty of Medicine, The University of Hong Kong, \\ Queen Mary Hospital, Pokfulam, Hong Kong, China
}

\begin{abstract}
IGF-I has profound effects on the immune system. We previously reported that IGF-I promoted cord blood (CB)-naïve T-cell maturation and now show that IGF-I promoted maturation of CB monocyte-derived dendritic cells (DC) with up-regulation of CD83, CD86, CD40, and major histocompatibility complex (MHC) class II molecules, and down-regulation of mannose receptor. Furthermore, IGF-I inhibited apoptosis of CB DC and increased the production of tumor necrosis factor $\alpha$ (TNF- $\alpha$ ). These effects were blocked by specific mitogen-activated protein kinase kinase (MEK) inhibitor (PD98059) and phosphoinositol 3-kinase inhibitor (LY294002). PD98059 partially inhibited the IGF-I-induced up-regulation of MHC class II. In contrast, LY294002 was additive in the IGF-I-induced up-regulation of MHC class II. Moreover, LY294002 significantly increased the percentage of late apoptotic cells in CB. These results imply the involvement of different pathways for the differential regulation of co-stimulatory molecule expression and apoptosis. The addition of anti-TNF- $\alpha$ did not neutralize the effects of IGF-I on CB
\end{abstract}

ABSTRACT

DC maturation and apoptosis. On the contrary, neutralizing TNF- $\alpha$ significantly increased the IGF-I-induced up-regulation of CD83 and CD40. We conclude that IGF-I has maturation and survival effects on CB DC. These effects are mediated through both MEK and PI 3-kinase pathways but not through the IGF-I induction of TNF- $\alpha$ production by the DC. (Pediatr Res 54: 919-925, 2003)

AV, annexin V Abbreviations
CB, cord blood
DC, dendritic cells
MEK, mitogen-activated protein kinase kinase
MHC, major histocompatibility complex
MR, mannose receptor
PI, propidium iodide
PI 3-kinase, phosphoinositol-3-kinase
TNF- $\alpha$, tumor necrosis factor $\alpha$

AV, annexin V

CB, cord blood

DC, dendritic cells

MEK, mitogen-activated protein kinase kinase

MR, mannose receptor

PI, propidium iodide

TNF- $\boldsymbol{\alpha}$, tumor necrosis factor $\alpha$ 
tivity and induces TNF- $\alpha$ production from monocytes (13-15). IGF-I could also stimulate human B-cell proliferation and antibody secretion (16-18). Moreover, it has potential to augment lectin or anti-CD3 stimulated T-cell proliferation $(4,19)$. Our previous observations show that IGF-I not only promotes $\mathrm{CB}$ T-cell maturation in interferon $\gamma$ production and CD45RA/RO transformation, but also maintains survival and inhibits apoptosis of CB T cells $(4,20,21)$. We hypothesized that IGF-I may also modulate the maturation and survival of CB monocyte-derived DC.

The functions of IGF-I are mediated by the IGF-I receptor (IGF-IR), a highly specific membrane receptor associated with intracellular tyrosine kinase, homologous to the insulin receptor (22). Studies on signaling by the IGF-I and IGF-IR in different cell types have revealed two primary pathways by which these signals might be transmitted (23). Two primary substrates of the activated IGF-IR are IRS-1 and Shc. Phosphorylated tyrosines on IRS-1 serve as docking sites for multiple proteins containing SH-2 domains $(24,25)$. Among these proteins, Grb-2 has been shown to bind to IRS-1 and activate Ras, in turn activating the Raf-MAP kinase pathway (26). The second pathway is the PI 3-kinase pathway. Association of IRS-1 with p85/p110 PI 3-kinase results in its activation (24). Because the involvement of MEK and PI 3-kinase has been implicated in previous studies $(27,28)$, specific MEK inhibitor (PD98059) and PI 3-kinase inhibitor (LY294002) were used to study the intracellular signaling pathways involved. Cytokineneutralizing antibodies were also used to determine whether the effects of IGF-I are mediated through the up-regulation of cytokine production. IGF-I is a survival factor for many cell types (27-31). To the best of our knowledge, this is the first report on the effects of IGF-I on CB DC.

\section{METHODS}

Isolation of monocytes. Human umbilical $\mathrm{CB}$ was obtained from the placentae of normal, full-term infants, after the placentae were delivered and separated from the infants, with prior written informed consent of their mothers. The protocol was approved by the Ethics Committee of the University of Hong Kong. All samples were collected in heparinized flasks. Cord blood mononuclear cells (CBMC) were isolated from whole blood by centrifugation, using Ficoll-Hypaque gradients (Pharmacia Biotech, Uppsala, Sweden). CBMC at the interface were collected, washed, and resuspended at $1 \times 10^{8} / \mathrm{mL}$ in $\mathrm{pH}$ 7.2 Hanks/HEPES buffer. Monocytes were isolated from mononuclear cells by positive selection using anti-CD14 conjugated magnetic microbeads (Miltenyi Biotec, Bergisch Gladbach, Germany). Cell viability, as measured by trypan blue exclusion, was more than $95 \%$. The purity of monocytes was measured by flow cytometry with $85-95 \%$ of the cells being CD14 positive.

Generation of immature $\mathbf{D C}$ in vitro. Isolated $\mathrm{CD} 14+$ monocytes were cultured at a density of $1 \times 10^{6}$ cells $/ \mathrm{mL}$ in RPMI 1640 (Sigma Chemical Co., St. Louis, MO, U.S.A.) plus $10 \%$ FCS supplemented with $50 \mathrm{IU} / \mathrm{mL}$ penicillin and 50 $\mu \mathrm{g} / \mathrm{mL}$ streptomycin (Invitrogen, Carlsbad, CA, U.S.A.). Monocytes were derived into immature DC in the presence of
IL-4 (10 ng/mL; R \& D Systems, Minneapolis, MN, U.S.A.) and granulocyte-macrophage colony-stimulating factor (GMCSF) $(50 \mathrm{ng} / \mathrm{mL} ; \mathrm{R} \& \mathrm{D}$ Systems $)$ at $37^{\circ} \mathrm{C}$ in a humidified atmosphere containing $5 \% \mathrm{CO}_{2}$, as in our previous study (10). The cultures were fed with fresh medium and cytokines after $3 \mathrm{~d}$ and cell differentiation was monitored by light microscopy. After $5 \mathrm{~d}$ culture, cells were harvested and washed three times with serum-free, hormone-free, and insulin-free Dulbecco's Modified Eagle Medium (DMEM)-F12 medium (Sigma Chemical Co.). Cells were then resuspended in DMEM-F12 plus IL-4 and GM-CSF with or without IGF-I (100 ng/mL, R $\&$ D Systems) for 2 more days. The concentration of IGF-I used has been titrated in previous studies $(4,20,21)$.

Immunofluorescence staining. After $7 \mathrm{~d}$ culture as described above, cells were collected, mixed with fluorochromeconjugated antibodies at concentration of $4 \mu \mathrm{g} / 10^{6}$ cells, washed, and resuspended in $300 \mu \mathrm{L}$ of wash solution for flow cytometric analysis. Isotype controls (FITC, PE, and PC5 conjugated) and CD14-FITC, CD83-FITC, CD86-FITC, CD40-FITC, MHC class II-FITC, and MR-PE were all purchased from BD PharMingen (San Diego, CA, U.S.A.).

Apoptosis assay with AV/PI. The percentage of cells undergoing apoptosis was determined by using the AV apoptosis kit (Immunotech-Coulter, Marseille, France) for the detection of membrane phosphatidylserine imbalance. According to the manufacturer's instructions, cells were resuspended in $300 \mu \mathrm{L}$ of ice-cold binding buffer. Five microliters of AV-FITC and 5 $\mu \mathrm{L}$ of PI $(1 \mathrm{mg} / \mathrm{mL})$ were added to the cell suspension. The cell suspension was kept on ice and incubated for $10 \mathrm{~min}$ in the dark before being analyzed by flow cytometry.

Signal analysis. Flow cytometric analysis was performed with a Coulter Epics Elite Flow Cytometer (Beckman Coulter, Inc., Fullerton, CA, U.S.A.). The machine was optimized daily using standard FlowCheck fluorescence beads (Beckman Coulter, Inc.) and linearity checked by Quantum 25 beads (Flow Cytometry Standards Corp, San Juan, PR, U.S.A.). Ten thousand events per sample were collected into listmode files and analyzed by the WinMDI 2.8 analysis software. The DC analysis was gated to the standard forward scatter and sidescatter profile for large cells.

Mixed lymphocyte reaction (MLR). In vitro-generated DC were washed with PBS, counted, resuspened, and treated with mitomycin C (10 $\mu \mathrm{g} / \mathrm{mL}$, Sigma Chemical Co.). Allogeneic $\mathrm{CB} \mathrm{CD}^{+} \mathrm{T}$ cells $\left(1 \times 10^{5}\right.$ responder cells/well $)$ were cultured in triplicate in 96-well flat-bottom microplates with different numbers of stimulator DC (DC to T cell ratios were 1:1000, 1:100, 1:10). Cultures were maintained in a humidified atmosphere at $37^{\circ} \mathrm{C}$ and $5 \% \mathrm{CO}_{2}$. Twenty microliters of $\mathrm{BrdU}(100$ $\mu \mathrm{M}$ ) was added into the wells $16 \mathrm{~h}$ before the end of $5 \mathrm{~d}$ culture and its incorporation was then measured by Cell Proliferation ELISA, BrdU (colorimetric) kit (Roche Molecular Biochemicals, Indianapolis, IN, U.S.A.).

TNF- $\alpha$ production by $D C$. The cell culture supernatants of non-IGF-I-treated and IGF-I-treated DC were harvested on d 7 and stored at $-20^{\circ} \mathrm{C}$ before analysis. The levels of TNF- $\alpha$ were measured by Quantikine ELISA kits (R \& D Systems). The detection range of TNF- $\alpha$ was $7.8-500 \mathrm{pg} / \mathrm{mL}$. 
A non IGF-I treated CB DCs IGF-I treated CB DC
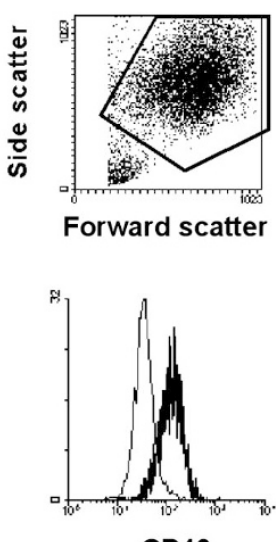

CD40
Forward scatter

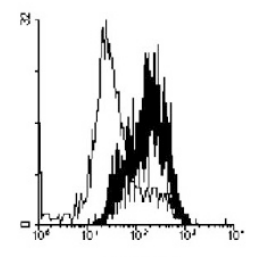

CD83

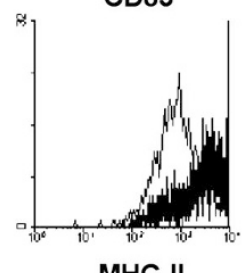

MHC-II

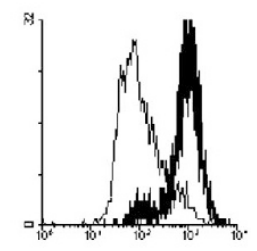

CD86

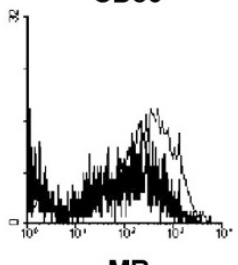

MR

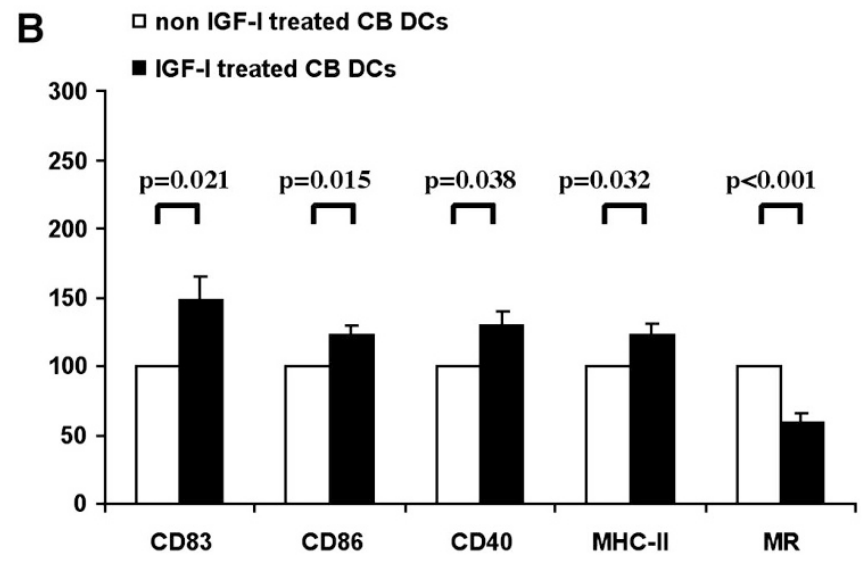

Figure 1. The expression of maturation markers on IGF-I-treated CB DC. $(A)$ IGF-I-treated CB DC (thick line) expressed higher levels of maturation markers than non-IGF-I treated CB DC (thin line). One representative experiment of more than five on different samples. $(B)$ To consolidate our findings, the expression levels of DC markers in IGF-I-treated CB DC were normalized to that in non-IGF-I-treated CB DC (CD83: $33 \pm 9$ MFL; CD86: $336 \pm 54$ MFL; CD40: $111 \pm 37$ MFL; MHC class II: $1274 \pm 168$ MFL; MR: $198 \pm$ 99 MFL). IGF-I significantly up-regulated the expression of CD83 $(n=9)$, CD86 $(n=11)$, CD40 $(n=5)$, and MHC class II molecules $(n=10)$ and down-regulated the expression of MR $(n=11)$. Results shown as mean \pm SEM.

Inhibition of signaling pathways. On d 5, CB monocytederived DC were preincubated for 30 min with MEK inhibitor PD98059 $(50 \mu \mathrm{M} / \mathrm{mL}$, Calbiochem, San Diego, CA, U.S.A.) or PI 3-kinase inhibitor LY294002 (25 $\mu \mathrm{M} / \mathrm{mL}$, Calbiochem) before the addition of IGF-I $(100 \mathrm{ng} / \mathrm{mL})$. The concentration of inhibitors used was based on previous literature (27) and preliminary titration experiments. The inhibitors were left in the medium throughout the whole period of IGF-I stimulation. Phenotypic expression, apoptosis analysis, and cytokine assays were performed on $\mathrm{d} 7$. The viability of cells on $\mathrm{d} 7$ was within the range of $65-85 \%$ as determined by trypan blue exclusion.

Neutralization of TNF- $\alpha$. Anti-TNF- $\alpha$ neutralizing antibodies $(10 \mu \mathrm{g} / \mathrm{mL}, \mathrm{R} \& \mathrm{D}$ Systems) were added into d $5 \mathrm{CB}$ monocyte-derived DC together with IGF-I $(100 \mathrm{ng} / \mathrm{mL})$ for a further $2 \mathrm{~d}$ in culture to inhibit the action of TNF- $\alpha$ on the cultured cells. The concentration used was based on the level

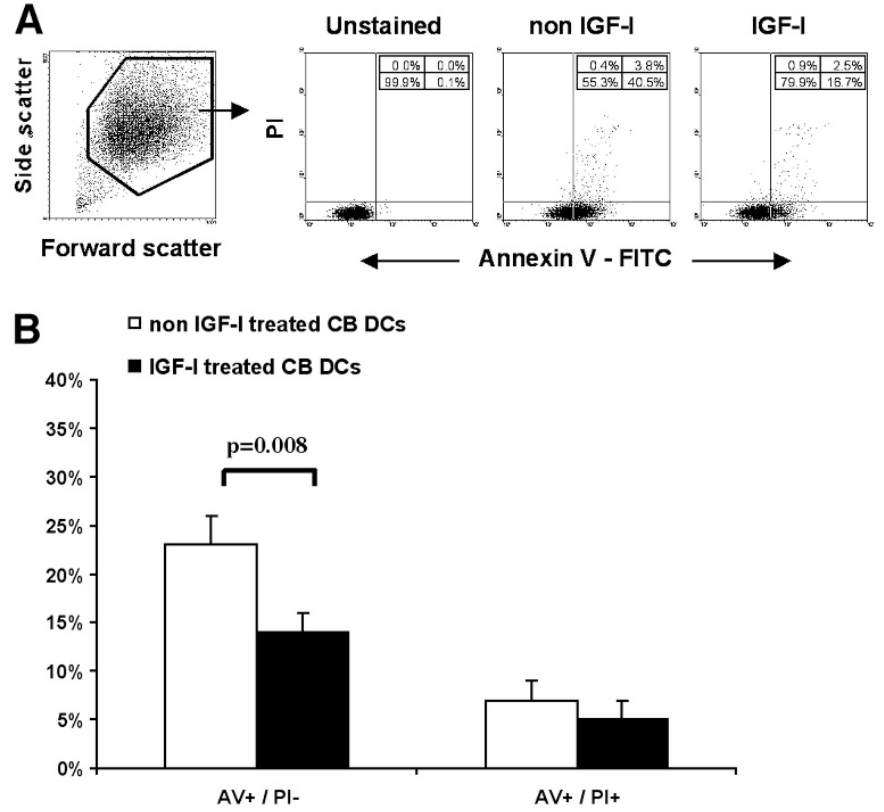

Figure 2. The early and late apoptosis in IGF-I-treated CB DC. (A) Early and late apoptosis was determined by AV labeling for membrane phosphatidylserine imbalance. One representative experiment of seven different samples. $(B)$ IGF-I reduced the percentage of early apoptotic cells $(\mathrm{AV}+/ \mathrm{PI}-)$ but had no effect on the percentage of late apoptotic cells (AV+/PI+). Results shown as mean $\pm \operatorname{SEM}(n=7)$

of TNF- $\alpha$ assayed in previous culture and the suggested neutralization dose provided by the manufacturer.

Data presentation and statistical analysis. In most cases, data were expressed as mean \pm SEM. To facilitate the presentation of results, the mean fluorescence level (MFL) of test samples was normalized to the respective controls and expressed as relative expression level according to the equation:

Relative expression level

$$
=\frac{\text { MFL of an antigen in test sample }}{\text { MFL of an antigen in control }} \times 100 \%
$$

All samples were paired and differences between groups analyzed by paired $t$ test or the nonparametric equivalents.

\section{RESULTS}

IGF-I promoted CB monocyte-derived DC maturation. The maturation of DC is marked by the up-regulation of costimulatory molecules and down-regulating the expression of MR (11). IGF-I significantly up-regulated the expression of CD83, CD86, CD40, and MHC class II molecules with downregulated MR expression. To facilitate the presentation of data, the expression levels of IGF-I-treated DC were normalized to that of the non-IGF-I-treated DC (Fig. 1).

IGF-I inhibited apoptosis in CB monocyte-derived DC. To determine whether IGF-I is a survival factor for CB DC, apoptosis was studied in serum-free culture with or without IGF-I by flow cytometry (Fig. 2A). The percentage of $\mathrm{AV}^{+} /$ $\mathrm{PI}^{-}$early apoptotic cells was decreased significantly in the IGF-I-treated DC $(n=7)$, but there was no significant differ- 


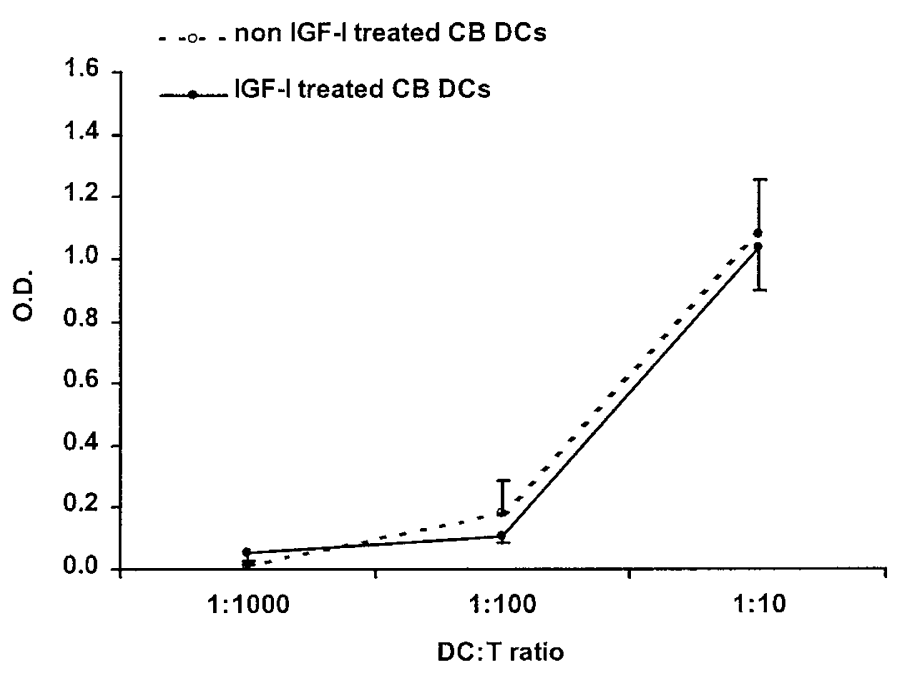

Figure 3. Proliferative response of $\mathrm{CB} \mathrm{CD}^{+} \mathrm{T}$ cell cultured with allogeneic non-IGF-treated or IGF-treated CB DC at different ratios. The abilities of IGF-treated and non-IGF-treated DC to stimulate the proliferation of $\mathrm{CD}^{+} \mathrm{T}$ cells were similar $(n=3)$. Results shown as mean \pm SEM.

ence in the percentage of $\mathrm{AV}^{+} / \mathrm{PI}^{+}$late apoptotic cells between the two groups (Fig. 2B).

IGF-I-treated CB monocyte-derived DC stimulated allogeneic lymphocyte proliferation. In vitro-generated DC were investigated for their ability to stimulate the proliferation of allogeneic $\mathrm{CB} \mathrm{CD}^{+} \mathrm{T}$ cells in MLR. Background BrdU uptake by either $\mathrm{CD}^{+}{ }^{+} \mathrm{T}$ cells $\left(1 \times 10^{5}\right)$ or mitomycin-treated DC was undetectable. Both non-IGF-treated and IGF-treated CB DC showed similar ability to stimulate $\mathrm{CD}^{+} \mathrm{T}$ cells at $\mathrm{DC}$ to $\mathrm{T}$ ratios of $1: 1000 ; 1: 100$, and $1: 10$ (Fig. 3 ).

IGF-I induced TNF- $\alpha$ production by $C B$ monocyte-derived $D C$. IGF-I alone induced TNF- $\alpha$ production from monocytes (15). We showed that IGF-I significantly induced TNF- $\alpha$ production by CB DC (Fig. 4). TNF- $\alpha$ production induced by IGF-I was completely blocked by PD98059 or LY294002.

MEK inhibitor PD98059 and PI 3-kinase inhibitor LY294002 blocked the effects of IGF-I on CB monocytederived DC maturation. The intracellular pathways triggered after IGF-I binding with IGF-I receptor have been identified mainly as the MEK and PI 3-kinase pathways $(24,25,28)$. To delineate the intracellular pathways of IGF-I effects on the CB DC maturation, PD98059 and LY294002 were used to inhibit the MEK and PI 3-kinase pathways, respectively. PD98059 completely blocked the effects of IGF-I on the expression of CD83, CD86, CD40, and MR in CB DC, whereas the expression of MHC class II molecules was only partially blocked (Fig. 5A). LY294002 had similar blocking effects for the expression of CD86 and CD40. Unexpectedly, it also downregulated CD83 expression and up-regulated MR and MHC class II expression (Fig. 5B).

MEK inhibitor PD98059 and PI 3-kinase inhibitor LY294002 blocked the effects of IGF-I on CB monocytederived DC apoptosis. MEK and PI 3-kinase pathways play very important roles in DC survival and apoptosis induced by LPS $(32,33)$. We investigated whether the effects of IGF-I on CB DC survival and apoptosis were also mediated through these two pathways. We showed that MEK inhibitor PD98059

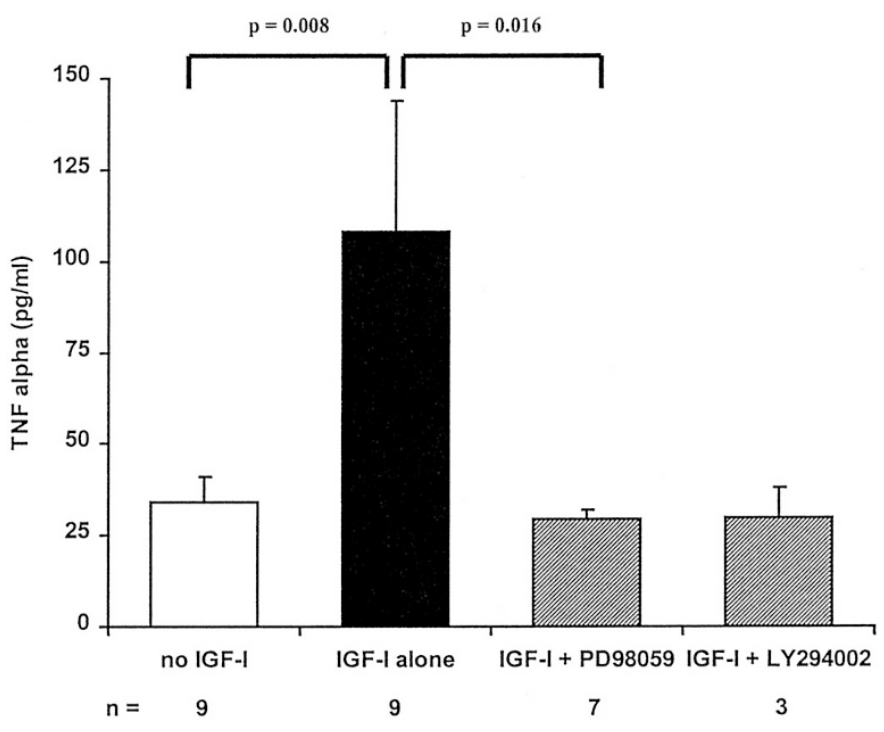

Figure 4. TNF- $\alpha$ production from IGF-I-treated and kinase inhibitor-treated CB DC. IGF-I induced significantly higher levels of TNF- $\alpha$ than in non-IGFtreated controls $(34 \pm 7 \mathrm{pg} / \mathrm{mL}$ vs $108 \pm 36 \mathrm{pg} / \mathrm{mL} ; n=9 ; p=0.008)$. The addition of PD98059 $(50 \mu \mathrm{M} / \mathrm{mL})$ or LY294002 $(25 \mu \mathrm{M} / \mathrm{mL})$ in cell culture for $30 \mathrm{~min}$ before the addition of IGF-I blocked the IGF-I induced TNF- $\alpha$ production. The mean $\pm \mathrm{SEM}$ was $30 \pm 2 \mathrm{pg} / \mathrm{mL}(n=7, p=0.016)$ and 30 $\pm 8 \mathrm{pg} / \mathrm{mL}(n=3)$ for PD98059 and LY294002, respectively.

inhibited the effects of IGF-I on CB DC apoptosis (Fig. 6A). Similar but not entirely identical results were obtained for PI 3-kinase inhibitor LY294002 (Fig. 6B). In contrast to $\mathrm{PD} 98059$, which had no effects on the percentage of $\mathrm{AV}^{+} / \mathrm{PI}^{+}$ late apoptotic cells, LY294002 could significantly augment the percentage of $\mathrm{AV}^{+} / \mathrm{PI}^{+}$late apoptotic cells in CB DC.

Anti-TNF-a could not neutralize the effects of IGF-I on the maturation and apoptosis of $C B$ monocyte-derived $D C$. Because TNF- $\alpha$ is a pivotal factor for DC maturation (34), we hypothesized that the effects of IGF-I on CB DC maturation and survival were mediated through TNF- $\alpha$. However, even high concentration of anti-TNF- $\alpha$ neutralizing antibody did not neutralize the effects of IGF-I on CB DC maturation (Fig. 7A). Anti-TNF- $\alpha$ even induced higher expression levels of maturation markers, in particular CD83 and CD40, on CB DC. The addition of anti-TNF- $\alpha$ did not have any effect on the IGF-I induced reduction of apoptosis in CB DC (Fig. 7B).

\section{DISCUSSION}

Regulation of inflammation and immunity requires a vast network of interacting cells and cytokines. The endocrine system participates in various ways in immune regulation, through the actions of GH and IGF-I (35). In our previous studies on mixed populations of CBMC, we have shown that IGF-I could promote $\mathrm{CB}$ naïve $\mathrm{T}$ cell maturation from CD45RA to CD45RO (21), induce IL-6 production and stimulate the phytohemagglutinin-induced interferon $\gamma$ secretion to adult level (4). IGF-I also maintains the survival and inhibits apoptosis of CB T cells (21) and increases the telomerase of CB T cells (20). In the present study, we further demonstrated that IGF-I promoted the $\mathrm{CB}$ monocyte-derived DC maturation with up-regulation of CD83, CD86, CD40, and MHC class II 
(a)

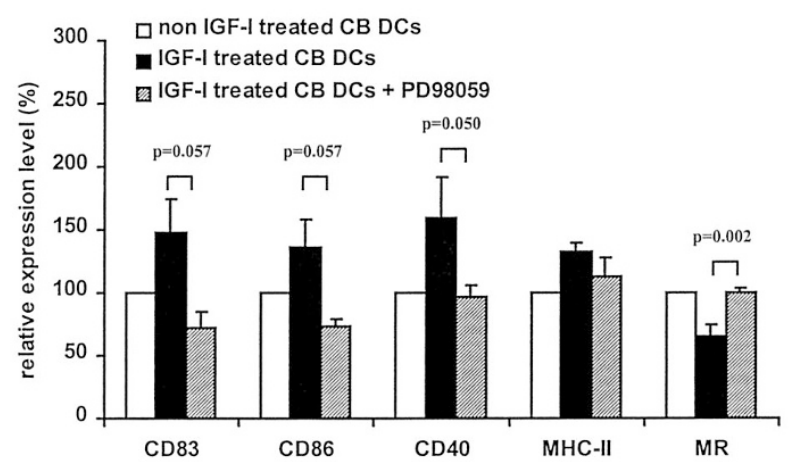

(b)

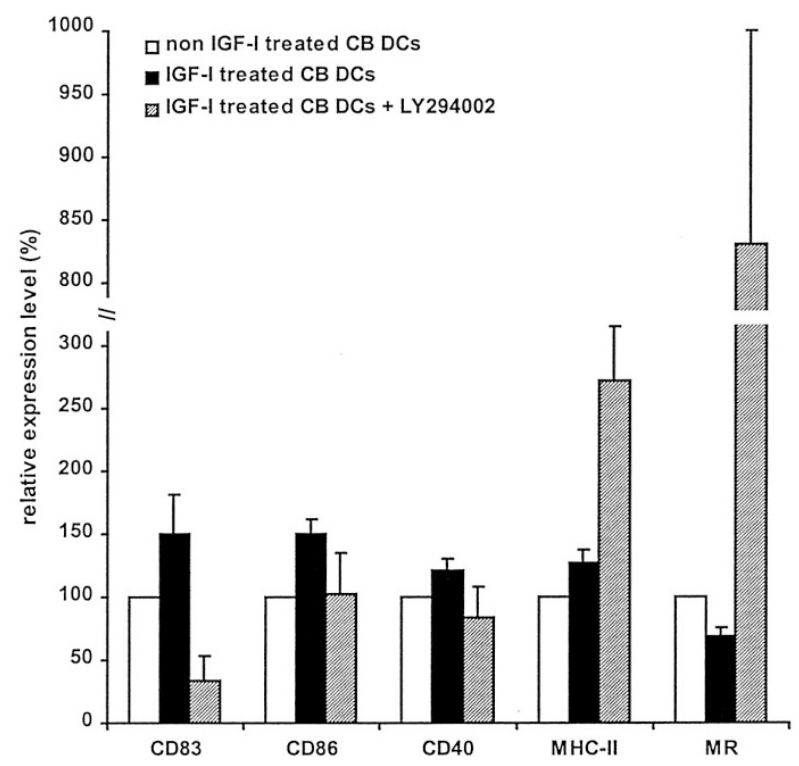

Figure 5. The expression of maturation markers on kinase inhibitors-treated CB DC. PD98059 $(50 \mu \mathrm{M} / \mathrm{mL})$ or LY294002 $(25 \mu \mathrm{M} / \mathrm{mL})$ were added in cell culture for $30 \mathrm{~min}$ before the addition of IGF-I. (A) PD98059 completely blocked the effects of IGF-I on the up-regulation of CD83, CD86, and CD40, and down-regulation of MR $(n=5)$. The IGF-I-induced up-regulation of MHC class II molecules was only partially blocked $(n=4)$. (B) Similarly, LY294002 blocked the effects of IGF-I on up-regulation of CD83, CD86, and CD40, and down-regulation of MR $(n=3)$. However, LY294002 downregulated CD83 expression and up-regulated MR and MHC class II molecules expression $(n=3)$. Results shown as mean \pm SEM.

molecules expression and down-regulation of MR expression (Fig. 1). Furthermore, IGF-I inhibited the apoptosis of CB DC and induced TNF- $\alpha$ production (Figs. 2 and 4). The effects of IGF-I were blocked by MEK inhibitor PD98059 and PI 3-kinase inhibitor LY294002 (Figs. 4-6) but not by anti-TNF- $\alpha$ neutralizing antibodies (Fig. 7). Our results indicate that IGF-I induced CB DC maturation is regulated by activation of both intracellular signaling routes but not through up-regulation of TNF- $\alpha$ production.

The number of DC in the circulation is scarce and the in vitro generation of monocyte-derived DC serves as an important tool for the study of DC biology. Maturation of DC is characterized by morphologic, phenotypic, and functional changes (36). We demonstrated clearly that IGF-I induced CB DC maturation with up-regulation of co-stimulatory and MHC class II molecule expression and down-regulation of MR ex- (a)

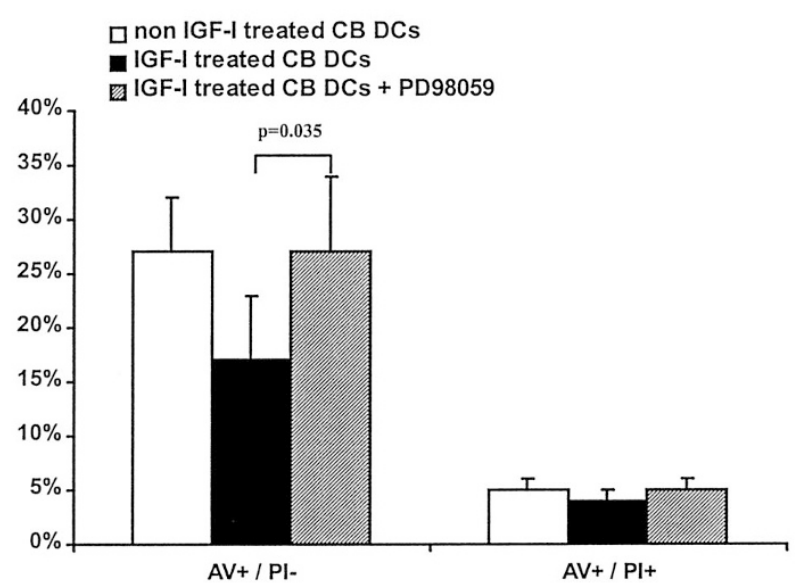

(b)

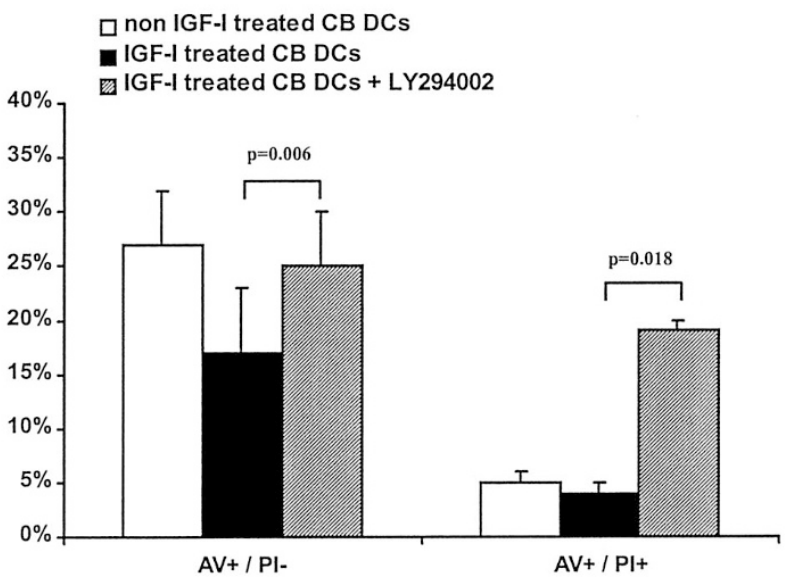

Figure 6. The early and late apoptosis in kinase inhibitor-treated CB DC. PD98059 $(50 \mu \mathrm{M} / \mathrm{mL})$ or LY294002 $(25 \mu \mathrm{M} / \mathrm{mL})$ were added in cell culture for 30 min before the addition of IGF-I. MEK inhibitor PD98059 $(A)$ and PI 3-kinase inhibitor LY294002 (B) completely blocked the effects of IGF-I on early apoptosis of CB DC. Moreover, LY294002 significantly increased the late apoptotic cells in CB DC. Results shown as mean $\pm \operatorname{SEM}(n=7)$.

pression. Even though an up-regulation of antigen presentation capacity was not detected in IGF-I-treated DC (Fig. 3), the increase in expression levels of co-stimulatory molecules was statistically significant (Fig. 1). In previous studies, the effect of IGF-I may have been amplified by limiting the amount of cytokines, such as IL-4, in the cultures. This experimental design is difficult to achieve in the study of monocyte-derived DC, as they require IL-4 and granulocyte-macrophage colonystimulating factor to maintain their stable differentiated stage (37).

The IGF-I induced maturation is mediated by the MEK pathway as shown after the addition of MEK inhibitor PD98059 (Fig. 5A). The involvement of the PI 3-kinase is, however, more complex. The addition of PI 3-kinase inhibitor LY294002 only blocked the IGF-I-induced up-regulation of CD86 and CD40. Interestingly, blocking the PI 3-kinase pathway led to reduced expression of CD83 and enhanced expression of MHC class II molecules and MR (Fig. 5B). It is possible that there are inhibitory factors in the system that are mediated through the PI 3-kinase pathway in down-regulating 
(a)

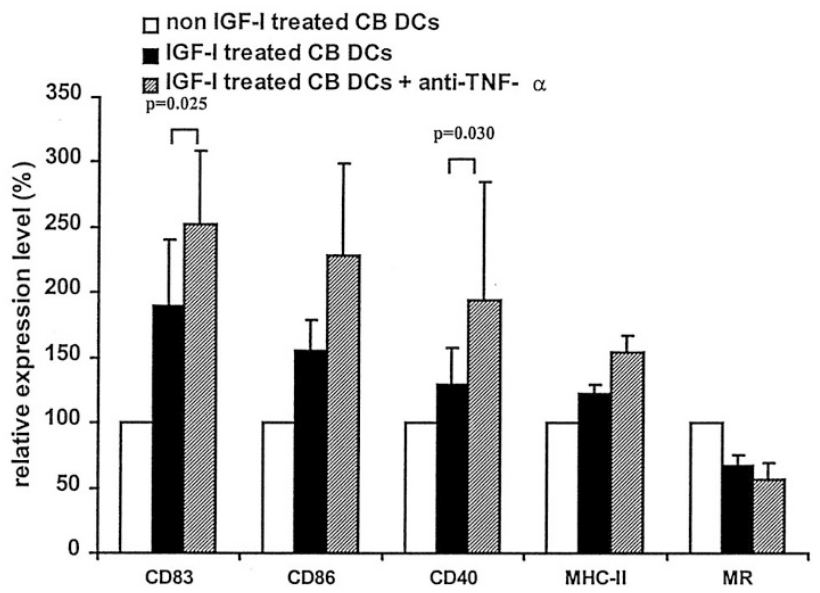

(b)

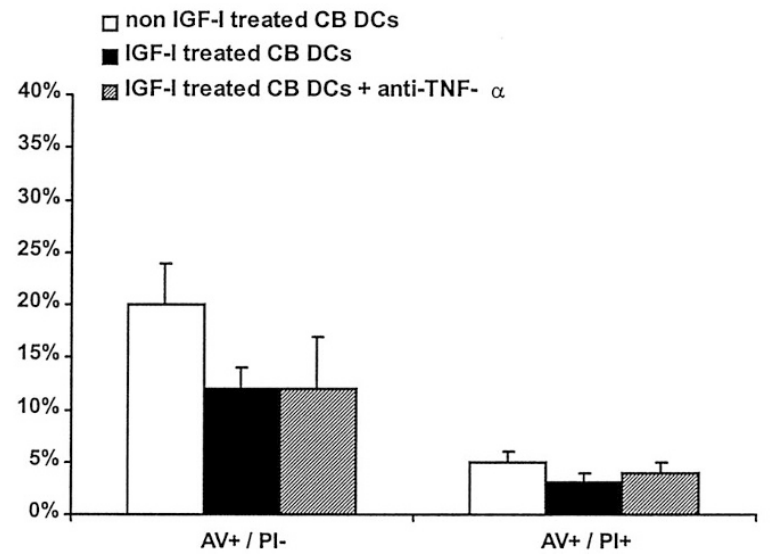

Figure 7. The expression of maturation markers and apoptosis in anti-TNF- $\alpha$ neutralizing antibody-treated CB DC. The addition of anti-TNF- $\alpha$ neutralizing antibody $(10 \mu \mathrm{g} / \mathrm{mL})$ did not neutralize the effects of IGF-I on CB DC maturation $(A)$ and apoptosis $(B)$. Unexpectedly, anti-TNF- $\alpha$ induced higher expression of maturation markers, in particular CD83 and CD40. Results shown as mean $\pm \operatorname{SEM}(n=7)$.

MHC class II molecule expression. Hence, blocking of inhibitory signals led to up-regulation of the molecules. Alternatively, there may be other maturation factors that share the PI 3-kinase pathway with IGF-I. Therefore, blocking of the pathway led to down-regulation of CD83 and up-regulation of MR. The role played by PI 3-kinase inhibitor alone and its interaction with molecules of the IGF-I signaling pathway will need to be investigated further.

It has been reported that IL-4 and IL-13 enhance fluid phase pinocytosis and MR-mediated uptake in human macrophages via the activation of PI 3-kinase (38). In rat liver endothelial cells, blocking PI 3-kinase pathway can suppress endocytosis that is due to both a reduction of the number of surface receptors and a reduction in the rate of receptor-ligand internalization (39). In this study, we did not investigate the pinocytosis or endocytosis function of $\mathrm{CB} \mathrm{DC}$, but our results showed that blocking the PI 3-kinase pathway significantly up-regulated MR expression, which may lead to increased MR-mediated endocytosis. Our results suggested that pinocytosis or endocytosis may be differentially regulated in different cell types and the mechanisms involved are worthy of further investigation.

IGF-I prevents apoptosis in a number of cell types, and acts as a survival factor in the absence of other factors (27-31). Specifically, IGF-I inhibits apoptosis of several IL-3dependent cell lines when IL-3 is removed $(30,40)$. IGF-I also inhibits spontaneous apoptosis in granulocytes (41). Recent studies demonstrated that PI 3-kinase is a critical cellular protein that prevents apoptotic cell death in many cell types, including hemopoietic progenitor cells and $\mathrm{T}$ lymphocytes (42). IGF-I can protect myeloid progenitor cells from apoptosis by activating PI 3-kinase. Previous studies have shown that MEK and PI 3-kinase are involved in the survival, whereas p38 stress-activated protein kinase (p38 SAPK) and nuclear factor $(\mathrm{NF})-\kappa \mathrm{B}$ family are involved in the maturation of human monocyte-derived DC induced by LPS $(32,33)$. In concordance with data published by Parrizas et al. (27) on rat pheochromocytoma cells, we demonstrated that IGF-I is capable of preventing apoptosis by activation of multiple signal transduction pathways. The fact that PI 3-kinase inhibitor LY294002 significantly increased the percentage of late apoptosis cells may be due to the blockade of signals from other cytokines, such as IL-4, which share the PI 3-kinase pathway with IGF-I (30).

TNF- $\alpha$ is one of the critical factors for DC maturation (34). Several TNF family members contribute to DC survival in addition to TNF- $\alpha$ itself. TNF-related activation-induced cytokine (TRANCE) is a DC-specific survival factor that regulates the expression of the anti-apoptotic molecule $\operatorname{Bcl}_{-} \mathrm{X}_{\mathrm{L}}(43,44)$. We showed that IGF-I could significantly increase TNF- $\alpha$ production from CB DC and either PD98059 or LY294002 completely blocked this effect (Fig. 4). Our results on CB DC agreed with the increased in vitro production of TNF- $\alpha$ by IGF-I reported on monocytes, macrophages, and granulocytes $(15,41)$. The TNF- $\alpha$ released was not responsible for the IGF-I-induced maturation and apoptosis in CB DC, as high concentrations of anti-TNF- $\alpha$ neutralizing antibody did not neutralize the effects of IGF-I on CB DC. On the contrary, neutralizing TNF- $\alpha$ could potentiate the effects of IGF-I in the up-regulation of maturation markers of $\mathrm{CB}$ DC, in particular CD83 and CD40 (Fig. 7). This effect of TNF- $\alpha$-neutralizing antibodies is similar to that of MEK inhibitors on TNF- $\alpha-$ stimulated cells reported recently by Puig-Kröger et al. (45). They demonstrated enhanced acquisition of maturation markers on DC when the TNF- $\alpha$ signaling pathway is blocked. The fact that blockade of the MEK pathway led to different cellular response in IGF-I- and TNF- $\alpha$-stimulated monocyte-derived DC implicated the specificity and complexity of the signal transduction pathways.

In cerebellar granule neurons, picogram amounts of TNF- $\alpha$ can potently inhibit both the IRS-2 phosphorylation and PI 3-kinase activation that play a pivotal role in IGF-I signaling (46). In this study, PI 3-kinase was also involved in IGF-Iinduced CB DC maturation. Hence, neutralizing TNF- $\alpha$ might decrease the inhibition of TNF- $\alpha$ on PI 3-kinase activity induced by IGF-I, leading to the additive effect of anti-TNF- $\alpha$ with IGF-I. The cross-talk by which vastly different receptors 
interact through sharing intracellular substrates such as PI 3-kinase needs to be studied further.

\section{CONCLUSION}

In conclusion, IGF-I not only promoted the maturation of CB monocyte-derived DC but also maintained the survival and inhibited the apoptosis of CB DC. In addition, IGF-I significantly induced TNF- $\alpha$ production. The maturation and survival of CB DC induced by IGF-I were mediated through both MEK and PI 3-kinase pathways. The effects of IGF-I on CB DC were not mediated by TNF- $\alpha$ inasmuch as anti-TNF- $\alpha$ antibody could not neutralize these effects. With the knowledge that IGF-I has positive effects on both $\mathrm{CB} T$ cells and DC, the use of IGF-I in designing a new strategy for ex vivo expansion of CB immunologic cells for immunotherapy and transplantation should be further explored.

Acknowledgment. The authors thank the staff of the labor ward, Tsan Yuk Hospital, in facilitating the collection of cord blood.

\section{REFERENCES}

1. Wilson CB 1986 Immunologic basis for increased susceptibility of the neonate to infection. J Pediatr 108:1-12

2. Wilson CB, Lewis DB 1990 Basis and implications of selectively diminished cytokine production in neonatal susceptibility to infection. Rev Infect Dis 12:S410S420

3. Suen Y, Lee SM, Qian J, van de Ven C, Cairo MS 1998 Dysregulation of lymphokine production in the neonate and its impact on neonatal cell mediated immunity. Vaccine 16:1369-1377

4. Tu W, Cheung PT, Lau YL 1999 IGF-I increases interferon-gamma and IL-6 mRNA expression and protein production in neonatal mononuclear cells. Pediatr Res 46:748-754

5. Hunt DW, Huppertz HI, Jiang HJ, Petty RE 1994 Studies of human cord blood dendritic cells: evidence for functional immaturity. Blood 84:4333-4343

6. Petty RE, Hunt DW 1998 Neonatal dendritic cells. Vaccine 16:1378-1382

7. Sorg RV, Kogler G, Wernet P 1999 Identification of cord blood dendritic cells as an immature CD11c- population. Blood 93:2302-2307

8. Goriely S, Vincart B, Stordeur P, Vekemans J, Willems F, Goldman M, De Wit D 2001 Deficient IL-12(p35) gene expression by dendritic cells derived from neonata monocytes. J Immunol 166:2141-2146

9. Liu E, Tu W, Law HK, Lau YL 2001 Changes of CD14 and CD1a expression in response to IL-4 and granulocyte-macrophage colony-stimulating factor are different in cord blood and adult blood monocytes. Pediatr Res 50:184-189

10. Liu E, Tu W, Law HK, Lau YL 2001 Decreased yield, phenotypic expression and function of immature monocyte-derived dendritic cells in cord blood. Br J Haematol 113:240-246

11. Zhou LJ, Tedder TF 1996 CD14+ blood monocytes can differentiate into functionally mature CD83 + dendritic cells. Proc Natl Acad Sci U S A 93:2588-2592

12. Kooijman R, Hooghe-Peters EL, Hooghe R 1996 Prolactin, growth hormone, and insulin-like growth factor-I in the immune system. Adv Immunol 63:377-454

13. Fu YK, Arkins S, Wang BS, Kelley KW 1991 A novel role of growth hormone and insulin-like growth factor-I. Priming neutrophils for superoxide anion secretion. J Immunol 146:1602-1608

14. Kooijman R, Willems M, De Haas CJ, Rijkers GT, Schuurmans AL, Van Buul-Offers SC, Heijnen CJ, Zegers BJ 1992 Expression of type I insulin-like growth factor receptors on human peripheral blood mononuclear cells. Endocrinology 131:22442250

15. Renier G, Clement I, Desfaits AC, Lambert A 1996 Direct stimulatory effect of insulin-like growth factor-I on monocyte and macrophage tumor necrosis factor-alpha production. Endocrinology 137:4611-4618

16. Landreth KS, Narayanan R, Dorshkind K 1992 Insulin-like growth factor-I regulates pro-B cell differentiation. Blood 80:1207-1212

17. Gibson LF, Piktel D, Landreth KS 1993 Insulin-like growth factor-I potentiates expansion of interleukin-7-dependent pro-B cells. Blood 82:3005-3011

18. Kimata H, Fujimoto M 1994 Growth hormone and insulin-like growth factor I induce immunoglobulin (Ig)E and IgG4 production by human B cells. J Exp Med 180:727732

19. Johnson EW, Jones LA, Kozak RW 1992 Expression and function of insulin-like growth factor receptors on anti-CD3-activated human T lymphocytes. J Immunol 148:63-71
20. Tu W, Zhang DK, Cheung PT, Tsao SW, Lau YL 1999 Effect of insulin-like growth factor 1 on PHA-stimulated cord blood mononuclear cell telomerase activity. $\mathrm{Br} \mathrm{J}$ Haematol 104:785-794

21. Tu W, Cheung PT, Lau YL 2000 Insulin-like growth factor 1 promotes cord blood T cell maturation and inhibits its spontaneous and phytohemagglutinin-induced apoptosis through different mechanisms. J Immunol 165:1331-1336

22. Czech MP 1989 Signal transmission by the insulin-like growth factors. Cell 59:235238

23. Rubin R, Baserga R 1995 Insulin-like growth factor-I receptor. Its role in cell proliferation, apoptosis, and tumorigenicity. Lab Invest 73:311-331

24. Myers Jr MG, Sun XJ, Cheatham B, Jachna BR, Glasheen EM, Backer JM, White MF 1993 IRS-1 is a common element in insulin and insulin-like growth factor-I signaling to the phosphatidylinositol 3'-kinase. Endocrinology 132:1421-1430

25. Sasaoka T, Rose DW, Jhun BH, Saltiel AR, Draznin B, Olefsky JM 1994 Evidence for a functional role of She proteins in mitogenic signaling induced by insulin, insulin-like growth factor-1, and epidermal growth factor. J Biol Chem 269:1368913694

26. Cobb MH, Goldsmith EJ 1995 How MAP kinases are regulated. J Biol Chem 270:14843-14846

27. Parrizas M, Saltiel AR, LeRoith D 1997 Insulin-like growth factor I inhibits apoptosis using the phosphatidylinositol 3'-kinase and mitogen-activated protein kinase pathways. J Biol Chem 272:154-161

28. Minshall C, Arkins S, Dantzer R, Freund GG, Kelley KW 1999 Phosphatidylinositol 3'-kinase, but not S6-kinase, is required for insulin-like growth factor-I and IL-4 to maintain expression of Bcl-2 and promote survival of myeloid progenitors. J Immunol 162:4542-4549

29. Minshall C, Arkins S, Freund GG, Kelley KW 1996 Requirement for phosphatidylinositol 3'-kinase to protect hemopoietic progenitors against apoptosis depends upon the extracellular survival factor. J Immunol 156:939-947

30. Minshall C, Arkins S, Straza J, Conners J, Dantzer R, Freund GG, Kelley KW 1997 IL-4 and insulin-like growth factor-I inhibit the decline in Bcl-2 and promote the survival of IL-3-deprived myeloid progenitors. J Immunol 159:1225-1232

31. Parrizas M, LeRoith D 1997 Insulin-like growth factor 1 inhibition of apoptosis is associated with increased expression of bcl-xL gene product. Endocrinology 138:1355-1358

32. Rescigno M, Martino M, Sutherland CL, Gold MR, Ricciardi-Castagnoli P 1998 Dendritic cell survival and maturation are regulated by different signaling pathways. J Exp Med 188:2175-2180

33. Ardeshna KM, Pizzey AR, Devereux S, Khwaja A 2000 The PI3 kinase, p38 SAP kinase, and NF-kappaB signal transduction pathways are involved in the survival and maturation of lipopolysaccharide-stimulated human monocyte-derived dendritic cells. Blood 96:1039-1046

34. Sato K, Nagayama H, Tadokoro K, Juji T, Takahashi TA 1999 Extracellular signalregulated kinase, stress-activated protein kinase/c-Jun N-terminal kinase, and p38mapk are involved in IL-10-mediated selective repression of TNF-alpha-induced activation and maturation of human peripheral blood monocyte-derived dendritic cells. J Immunol 162:3865-3872

35. Heemskerk VH, Daemen MA, Buurman WA 1999 Insulin-like growth factor-1 (IGF-I) and growth hormone $(\mathrm{GH})$ in immunity and inflammation. Cytokine Growth Factor Rev 10:5-14

36. Banchereau J, Briere F, Caux C, Davoust J, Lebecque S, Liu YJ, Pulendran B, Palucka K 2000 Immunobiology of dendritic cells. Annu Rev Immunol 18:767-811

37. Romani N, Reider D, Heuer M, Ebner S, Kampgen E, Eibl B, Niederwieser D, Schuler G 1996 Generation of mature dendritic cells from human blood. An improved method with special regard to clinical applicability. J Immunol Methods 196:137-151

38. Montaner LJ, da Silva RP, Sun J, Sutterwala S, Hollinshead M, Vaux D, Gordon S 1999 Type 1 and type 2 cytokine regulation of macrophage endocytosis: differential activation by IL-4/IL-13 as opposed to IFN-gamma or IL-10. J Immunol 162:4606-4613

39. Kjeken R, Mousavi SA, Brech A, Griffiths G, Berg T 2001 Wortmannin-sensitive trafficking steps in the endocytic pathway in rat liver endothelial cells. Biochem J 357:497-503

40. Kulik G, Weber MJ 1998 Akt-dependent and -independent survival signaling pathways utilized by insulin-like growth factor I. Mol Cell Biol 18:6711-6718

41. Kooijman R, Coppens A, Hooghe-Peters E 2002 IGF-I inhibits spontaneous apoptosis in human granulocytes. Endocrinology 143:1206-1212

42. Kulik G, Klippel A, Weber MJ 1997 Antiapoptotic signalling by the insulin-like growth factor I receptor, phosphatidylinositol 3-kinase, and Akt. Mol Cell Biol 17:1595-1606

43. Wong BR, Josien R, Lee SY, Sauter B, Li HL, Steinman RM, Choi Y 1997 TRANCE (tumor necrosis factor [TNF]-related activation-induced cytokine), a new TNF family member predominantly expressed in T cells, is a dendritic cell-specific survival factor. J Exp Med 186:2075-2080

44. Josien R, Wong BR, Li HL, Steinman RM, Choi Y 1999 TRANCE, a TNF family member, is differentially expressed on $\mathrm{T}$ cell subsets and induces cytokine production in dendritic cells. J Immunol 162:2562-2568

45. Puig-Kröger A, Relloso M, Fernandez-Capetillo O, Zubiaga A, Silva A, Bernabeu C, Corbi AL 2001 Extracellular signal-regulated protein kinase signaling pathway negatively regulates the phenotypic and functional maturation of monocyte-derived human dendritic cells. Blood 98:2175-2182

46. Venters HD, Dantzer R, Kelley KW 2000 Tumor necrosis factor-alpha induces neuronal death by silencing survival signals generated by the type I insulin-like growth factor receptor. Ann N Y Acad Sci 917:210-220 